\title{
SELECTED PROBLEMS OF PUBLIC ADMINISTRATION OFFICIALS
}

\author{
Lucie Kamrádová ${ }^{1}$, Marie Sciskalová ${ }^{2}$ \\ Faculty of Public Policies in Opava, Silesian University in Opava, Bezručovo nám. 885/14, \\ 74601 Opava, Czech Republic \\ E-mails: ' lucie.kamradova@fvp.slu.cz (corresponding author); ${ }^{2}$ marie.sciskalova@fvp.slu.cz \\ Received 27 February 2020; accepted 07 May 2020
}

\begin{abstract}
The aim of the article is to present the position of public administration officials with a focus on the Czech Republic as an example of good practice. In today's globalized society, the term clerk (or official) appears in a rather negative connection, following the organizational structure and bureaucratic apparatus. However, it is difficult to identify from the perspective of the media and the society itself what the view of the officials themselves on their profession and the difficulty of this profession is. The aim of the paper is to describe the position of the official and his/her performance connected with the view of the difficulty of this profession. The paper uses quantitative research methods through a questionnaire survey in public administration aimed at officials as respondents. Other methods used in the paper are analysis, comparison and description. All these methods of research give an overview of the selected view of officials on the performance of their profession in the selected group.
\end{abstract}

Keywords: clerk, officials, law, satisfaction, management.

JEL Classification: H83, L32.

\section{Introduction}

The Ministry of the Interior of the Czech Republic, in the published code of ethics of officials and employees working in public administration, states at the outset that "every official and employee of public administration is obliged to respect and respect the legality of all procedures and equal access to to all natural and legal persons. The purpose of this Code is to create, maintain and deepen public confidence in public administration'. From the foregoing it is clear that the preamble to the preamble reveals the difficulty of this profession, which is, without a doubt, the status of civil servant. The aim of the paper is to clarify and focus on selected problems of this profession towards the performance of clerical profession. The position of officials is not easy at all, not only in the Czech Republic but in the globalized world. They are required by law to observe the principles of state administration. Their profession is directly related to the law and is associated with it without exception. The paper will focus on the basic characteristics and definition of an official not only in the Czech Republic. Subsequently, it defines the problems commonly encountered in the performance of state administration. Basic risks and opinions of the officials themselves on selected problems will be identified. The analysis of these opinions was carried out by means of a questionnaire survey, which was attended by over one hundred respondents performing this preference in the selected region.

The paper will use methodological methods of analysis, synthesis, induction, and deduction. The methodological basis of the research follows the objective of the paper, which is selected problems of employees in public administration with a particular focus on the Czech Republic. The method of analysis serves to divide more complex facts into simpler parts, according to common or different features. This research method will be used mainly in the introductory chapter, but its features will be found throughout the text. Synthesis is a true opposite, thus combining several elements into a whole. This method is noticeable in the paper mainly in defining the risks of the profession of officials as well as in the critical areas of their performance. The mentioned methods will be followed by induction and deduction, which are used mainly in the field of secondary data in the last chapter of the paper. A method that is indispensable for the contribution is a description, ie description of the existence of phenomena and their properties. Without this method, the contribution would lose its meaning (Hendl, 2005). The defined objective of the work, thus defining and describing selected problems of public administration officials, will be supported by quantitative research carried out by authors of the work based on a question- 
naire survey among officials in the Czech Republic and participants in administrative proceedings.

This paper will serve as a marginal insight into the performance of the civil servant's profession and may serve as a basis for further comparison of civil servants' activities in each country. The sources used in the text I at the end of the article are not only from the relevant laws, professional literature and available publications, but also use the findings of the research conducted by the authors of the article.

\section{Human resources in public administration}

In the past, the issue of human resources was addressed by Max Weber, who considers the socalled signs of "inhumanity" to be ideal. At present, society is turning rather to the negative side of public administration and regards officials as persons who tend to damage public administration by their position. However, Professor de Vries points out that there is, first and foremost, much more to be done to make people feel proud to serve the public. To constantly criticize and complain about bureaucracy is not going anywhere. It can be stated that without state administration, including the provision of a public office at the level of municipalities and regions, it would not be possible for public administration matters. However, the public is little aware of this fact (Wiesnerová, 2015). Thus, this chapter will focus on the basic definitions and characteristics that relate directly to officials. These are, in particular, terms such as human resource, civil servant, service, civil service and public service. It is important to define this theoretical basis, as the follow-up research will cover only a selected sector of government at the territorial level.

Peter F. Drucker states that people are the largest capital. It is undeniable that the term is based on the private sector, but at present the strictly defined boundary between private and public is lost (concepts of social responsibility, PPP, etc.). Mr T. Ciceron (Philosopher, 106-43 BC) describes the official as a person who is to be aware that "his task is to represent the community, protect its dignity and honor, uphold the law, rule on the law and remember that all of this has been entrusted to his conscience" (Miller, 2000). The above definition appeals to the issue of the use of human resources in the area of public administration and appeals to the difficulty of this profession. For this reason, personnel issues are one of the basic components of administrative science and administrative policy, which are generally classified as public admin- istration. The institute of the profession of civil servant and its establishment is closely connected with the promotion of the state ideas of the 18th century European states, which were constituted on the territorial principle. On this basis, however, the relationship between the monarch and his official has received certain "fiscal dependencies", such as loyalty, the peculiarities of the Monetary relationship, which have been expressed by some kind of clerical ethos and law. It is a period in which bureaucracy arises as a special profession. In modern times, public administration has become more open and thus more transparent and controllable. It takes on the nature of a service to the public and ceases to be understood only as a ruling authority (Zimek, 2010). This is connected with the transformation of the role of public administration employee. The new role of an official (authorized official) of public administration is also related to his relationship with politics. It's a contradictory relationship. Naturally, public administration is the realization of the policies of the state, municipality, region or other public administration bearer. For this reason, it retains its importance in the modern democratic state, and the aforementioned expression of loyalty, but also in the sense of neutral and loyal administration in the public interest, regardless of the immediate composition of the governing body. Ordering such fidelity does not mean that a public servant is to be restricted in his lifelong duties, for unjustified privilege and inequality, for guaranteed career advancement, and as a barrier to those who stand apart from the state apparatus. Reference is also made to the decreasing efficiency of the civil service profession. These include in particular the anonymity and isolation of officials, the maintenance of unnecessary official secrecy, the solidarity of the bureaucracy externally, which makes it opaque and leads to the irresponsibility of individual officials, respectively. corruption, as well as delays in handling the affairs of citizens and other parties to administrative proceedings. The decreasing efficiency of the clerical profession is associated with a tendency to inertia and comfort (which is often not true) (Frederickson et al., 2012). If a definition is to be sought in the legal order, we can find it in the Czech Republic specifically in Act No. 312/2002 Coll., On Officials of Territorial Self-governing Units, as amended (hereinafter the Officials Act). In this case, the cited Act defines an official as (provision of $\S 2$ (4)) an employee of a territorial self-governing unit involved in the performance of administrative activities. For the purposes of law, administrative activities shall mean the performance of tasks in the independent 
or delegated competence of the territorial selfgoverning unit according to special legal regulations.

The following terms "service relationship", "civil service" and "public service" relate to the exercise of a civil servant's profession and thus directly to human resources as such. The service relationship is generally based on Act No. 234/2014 Coll., On Civil Service, as amended. It is a contractual relationship between an employee and an employer, which is the state. The subject is a work activity that a public servant undertakes to perform for a salary (not a wage) for an employer. In the Czech Republic, it is governed by the relevant legal regulations, in particular Act No. 234/2014 Coll., On the Civil Service and Act No. 361/2003 Coll., On the service relationship of members of security forces. The employment relationship may be concluded for an indefinite period of time or possibly for a definite period of time, after which time it ends. The service relationship takes into account in a certain way the specific position of civil servants in comparison with employees in normal employment relationships, resp. employment. There are various statutory restrictions on employees in this relationship, as well as certain benefits (eg there may be legally limited options for termination or specifically modified severance payments). The term civil service is used only for employees of the state. However, this civil service is a narrower term than the public service, which also applies to employees of other public administration holders. In the conditions of the Czech Republic, the difference may also be expressed by the fact that an employee of another public administration holder (eg a municipality or a region) may have a different legal regime than an employee of the state. The public service as an administrative activity can then be divided from various points of view, for example according to the duration of the activity, the appointment to the function, or the method of implementation (Pavlík et al., 2014).

\section{Public administration in the Czech Republic and its classification}

Public administration in the Czech Republic has undergone a significant transformation, namely since 1993, when it became an independent democratic state. Since 1989 it has been defined as democratic, but it was still part of the Czechoslovak state. However, this was changed by Constitutional Act No. 1/1993 Coll.

The road to modern democratic public administration has led to considerable reforms that have taken place in two phases. The first was the establishment of regions and the transfer of a wide range of competencies from the central state administration to the territorial self-government. The second meant the abolition of district offices and the transfer of competencies in public administration to regions and municipalities. The result of the second phase of the reforms was therefore the creation of municipalities with a delegated municipal authority and the determination of municipalities with extended powers (Act No. 314/2002 Coll.). It can therefore be stated that in the present democratic Czech Republic there is a so-called two-tier system of territorial self-government, which consists of municipalities, which are basic territorial selfgoverning units and regions that are higher territorial self-governing units (including the City of Prague). In the case of autonomous competence, we are talking about self-government within which municipalities or regions administer their affairs independently, on their own account, in their own name, being bound only by laws and other legal regulations. The principle of subordination does not apply here. The delegated competence concerns the exercise of state administration, which is not carried out directly by the state by its own authorities, but indirectly, through the bodies of local self-government. The principle of subordination applies.

In the Czech Republic, the so-called joint model of public administration was chosen. that municipalities and regions carry out in addition to self-governing powers also state administration in delegated powers. There are also state administration authorities in the territory (eg financial administration, social security administration), but these are in the nature of specialized bodies for individual branches or their parts, the state administration body with general competence in the territory does not operate in the combined model. Selfgovernment performance is also based on the principle of decentralization in the combined model, ie self-government is not subordinate to the state and lower self-government is not subordinate to higher self-government (Ministry of the Interior Czech Republic, 2018).

\subsection{The position of civil servants}

In the Czech Republic, the key law for the characteristics of the civil servant profession is Act No. 312/2002 Coll., On officials of self-governing units and on amendments to certain laws (hereinafter the Act on Officials). This Act regulates the employment of officials and their training. Thanks to this Act, the profession of an official is also con- 
sidered in the Czech Republic as an employee of the office of a territorial self-governing unit, who participates in the performance of administrative activities while being included in the office of the given local self-governing unit. The abovementioned Act does not apply to employees classified in organizational units of territorial administrative unit, employees classified only in its special bodies and employees who perform exclusively socalled service activities or who manage the performance of such activities. It also does not apply to members of elected bodies of territorial selfgoverning units, nor to those persons whose employment relationship with the given territorial self-governing unit is given by an agreement on work performance or agreement on work activity, even if these persons were participated in the performance of administrative activities. These laborlaw relationships are governed by the Labor Code, not the Act on Officials. Interestingly, the Act on Officials beyond the Labor Code lays down the preconditions for the employment of an official. Thus, an official may become a natural person who is a Czech citizen or a natural person who is a foreign citizen but who has a permanent residence in the Czech Republic provided that he / she has reached the age of eighteen, and / or legal capacity; language and meets the prerequisites for carrying out administrative activities set out in a special legal regulation (Kamrádová \& Sciskalová, 2019).

The law clearly states that the duty of an official is to act in the public interest, to act and decide impartially, to comply with constitutional regulations, laws and other legal regulations. Another duty of an official outside the above is his obligation to refrain from such conduct that would seriously undermine the credibility of the territorial self-suffering unit (municipality, region). The position of employees in public administration is not only related to the actual adjustment of the conditions stipulated by the law for the conclusion of an employment contract, but also mainly to further education, which is obligatory for civil servants in the Czech Republic (Institute for Public Administration Prague, 2019). Territorial self-governing unit (region, municipality) provides education through accredited educational institutions. Each official must have a timetable for upgrading the official's qualifications. This plan shall be drawn up by the Territorial Self-Governing Unit no later than one year after the official's entry into service. The plan must include at least eighteen days' education over the next three years. It is the duty of the clerk to deepen the qualifications of the individual parts in initial and continuing education and in the preparation and verification of special expertise. This education is completed by a proficiency test. (Act No. 312/2002 Coll., On official selfgoverning units).

Despite the above-mentioned demands that are imposed on employees in public administration from the perspective of the law, there are still others that can be defined from the so-called social point of view, which include psychological, social, ethical, cultural and social claims. Each of these claims entails mainly the resilience and readiness of individual officials to deal with situations they may not always be prepared for. Among them we can also include the issue of aggressive client, which appears in today's society more and more often. The question concerning aggressive clients and meeting them in the performance of their profession was part of the research of the authors, which was conducted from July to December 2019 in the selected region in the Czech Republic. The research was focused on officials of self-suffering units and besides their position also focused on the mentioned issue. Altogether 234 officials participated in the survey and from them alarming $81 \%$ replied that they not only met an aggressive client in their profession but also felt their aggression through verbal attacks, threats, physical assault, family assault, personal property destruction ( such as cars, house damage), unjustified criminal complaints, bullying, complaints, lying, etc. The answers to the above questions are shown in Figure 2. Which percentage expresses the means used by aggressive clients towards officials. Figure 1 shows the number of officials who answered whether or not they had met an aggressive client in the exercise of their profession.

It is interesting how this topic provokes prosilent discussions. With regard to this fact, the clients of the authorities whose officials answered the question of the aggressive client were also contacted in the region. The clients themselves felt in this respect, however, affected by the so-called aggressive clerk. Their aggression manifested eg.

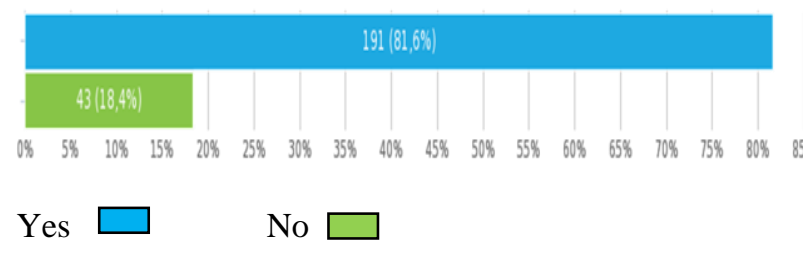

Figure 1. Number of officials meeting an aggressive client (Kamrádová \& Sciskalová 2019)

It is clear from the above that an aggressive client encounters a considerable part of the office 
staff very often. Only $18 \%$ of the survey participants did not see this type of clenta.

Interestingly, a significant number of authorities already routinely envisage an aggressive or otherwise negative client, for example, the City of York, England, has issued a manual on how to treat clients (instructions are mandatory). Part of the handbook is also a procedure how to treat a problem or aggressive client. For example, the official's recommendation is to maintain calmness, smile, use assertiveness, and only in extreme cases is the official allowed to leave the counter (Bagarova Grzywa, 2002). In the questionnaire survey of the authors of the article, the question of a manual for meeting an aggressive client also appeared, only $36 \%$ of respondents said that the manual was available to their bureau for officials. $60 \%$ of participants would welcome this manual at the workplace (Kamrádová \& Sciskalová, 2019).

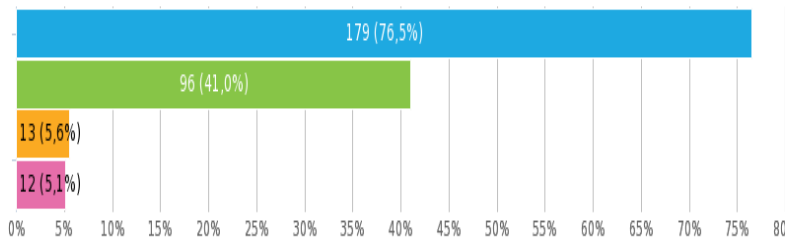

Verbal Attacks, Threats, Physical Assault, Others

Figure 2. Types of attacks of aggressive clients (Kamrádová \& Sciskalová, 2019)

As mentioned above, the clients also responded to the question of agrees in their dealings with the official. More than thirty percent said they had encountered an aggressive official, which is not as high as in the previous view, but this is alarming in relation to the professionalism of the officials. According to clients, the aggressiveness of officials was manifested, for example, by bias, superiority, arrogance or verbal attacks. This is indicated by Chart 3 below.

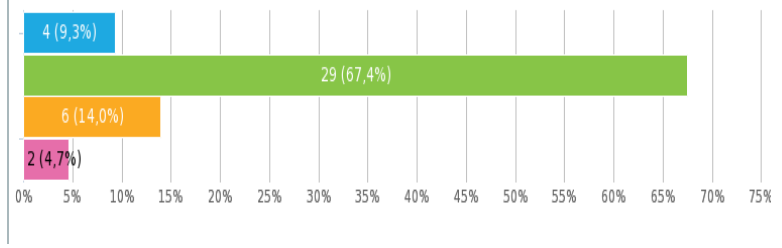

Captivity $\square$ Superiority $\square$ Insults $\square$ Other $\square$

Figure 3. Means of aggressive officials (Kamrádová \& Sciskalová, 2019)
However, one of the questions that has been raised with regard to public administration clients has also been aimed at officials who, on the other hand, were extremely willing to help clients solve their problems. It is positive that over eighty percent of those polled answered positively to the question and defined the official as being extremely willing to help them, being willing to advise them, or simply discussing their problem and proposing a solution beyond their competence within the office. This fact must also be taken into account as a shift from the negative social perception of officials to the positive.

Corruption is a very interesting area from the point of view of claims on civil servants and employees in public administration (the authors classify it as a group of so-called ethical claims). Corruption is generally considered a covert, unfair act. The authors often look at it similarly and exhaustively define it from various points of view (large, small, common, municipal, etc.). Professional qualification acquired in 2016. A total of one hundred and twenty officials working in public administration participated. When asked whether their code of ethics was applied in their office, seventy percent answered yes, which is a high percentage given the negative attitude of the public. Interestingly, however, was one of the questions relating to the relationship of the code of ethics to the behavior of officials and corruption. Three quarters of respondents replied that the Code of Ethics very well regulates the behavior and conduct of officials of territorial self-governing units (ie their workplaces) so as to prevent corruption. On the other hand, there are twenty percent of respondents who have no information at all. Here is the question for discussion, where is the problem? Inadequate information to the public or officials, or rather their superiors, who are responsible in this respect. Despite this fact, it is positive that these respondents have an overview of the basic rules of corruption. Ninety-nine percent of respondents answered correctly when asked about what is not corruption. Specifically, it was a choice of: receiving a bottle of alcohol, receiving a bouquet, providing cash, and providing counter-services. Respondents were well acquainted with the fact that only accepting a bouquet is not a corrupt act (Šabatová et al., 2017).

The issue of corruption has also been raised in the authors' questionnaire, both from the point of view of the officials themselves and from the point of view of clients who answered the question of whether they encountered corruption among officials and by what means. $80 \%$ of officials answered this question in the negative and another 
$20 \%$ omitted the question altogether. Against this fact, the participating clients, specifically, only ten percent of the participants who said they have encountered corruption of officials through small gifts, protectionism, clientelism and money.

One of the interesting areas of the civil servant's performance is also their remuneration, which is mainly governed by law. Given that public administration employees have considerably limited opportunities in any way other than those provided for by law, earnings, the financial remuneration should be sufficiently high in view of the difficulty and performance requirements of the profession. (Ticháčková, 2019) In the Czech Republic, there is a certain advantage that, during the practice, at least every two years the salary increase is ensured for officials by an average of CZK 1,500 (Pracomat, 2019). In practice, however, this is often different. Salaries in public administration are determined on the basis of pay tables for civil servants, this category, of course, also employees in public administration in general. In the salary table, it is possible to determine, on the basis of grade and step, to which basic salary a civil servant is entitled (Civil Service Act 234/2014 Coll.).

This question was also affected by the authors' questionnaire survey. As part of the clerical part of the questionnaire, officials were asked to answer a series of questions about the difficulty of their profession in terms of education, their entitlement to education and their social life, the public's view of their profession and, of course, their financial performance. Act. Sixty-six percent of respondents said that although the demands placed on public officials are much higher than in the public sector and the financial reward is not so great, they are willing to work in this sector for several reasons, including certain social security, social prestige and of course, a salary procedure. They consider the most demanding in their profession knowledge of law, responsibility, education and others (officials have written self-education, loyalty, decency, morality, ethics, mental resistance, etc.). The answers are shown in the graph. No. 4.

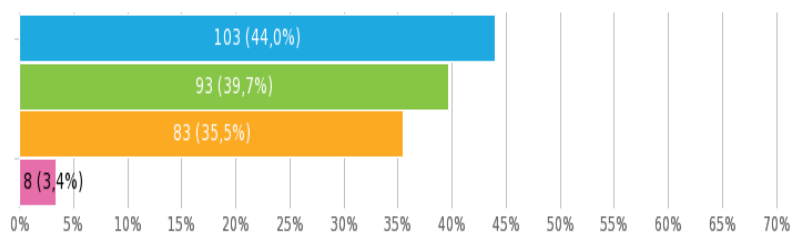

Law $\square$ Responsibility $\square$ Education $\square$ Other $\square$

Figure 4. Knowledge necessary for the performance of the official (Kamrádová \& Sciskalová, 2019)
It should be noted that, despite the many negative views not only of the company and the media on the performance of the civil servant profession, a positive view of their profession emerged from the perspective of clients. Eighty percent of the re-spondent said they were aware of the demands of the accounting profession. This includes work with people, entitlement to education, financial remuneration and responses to changes in law and other necessary methodology. Clients, however, recommend to the officials further development in terms of greater understanding of the problems of clients coming to the office, compliance with the code of ethics, more impartiality and independence, less bias, more consideration or study of law, willingness and smile.

The officials themselves were confronted with the view of the officials themselves and their performance by answering seven questions that had to be answered yes or no. These questions were:

- The profession of civil servant is viewed positively by the company.

- As an official in public administration, I feel my profession as a mission.

- The company perceives the profession of official negatively.

- In the public sector, employees are more restricted by law.

- The concept of bureaucracy in the negative sense of the public administration in the Czech Republic does not apply.

- At my workplace, I feel support and support in my superiors under the decentralization system.

- Benefits for civil servants have limits, which need to be constantly improved.

As mentioned above, officials have been involved in this survey for more than two hundred and some answers of these employees are highly alarming in terms of human pride in their profession and the position they occupy in the company. see above). For example, the first question when officials ask if their profession is perceived positively by over eighty percent of those involved responds negatively, a rather alarming figure in today's modern and educated society. Despite this fact, more than sixty percent of officials feel their profession as a mission they fulfill for the good of society. The third question only asks the answers of the individual officials to the first question and the fact that the company perceives the officials negatively. Yes, more than seventy-seven percent responded. The other two questions in the Yes / No series concern the performance of public administration and the position of individual officials 
therein. When asked about bureaucracy in public administration, most respondents answered that they were not aware of the negative meaning, but most of the officials feel their support and support at their workplace. Nevertheless, the last question about the limits of public administration in the temporal republic was clear, ninety-two percent of the respondent replied that the limits need to be constantly shifted and there is always room for further shift in it towards approaching the employees themselves but also clients. Graph 5 shows the answer in more detail.

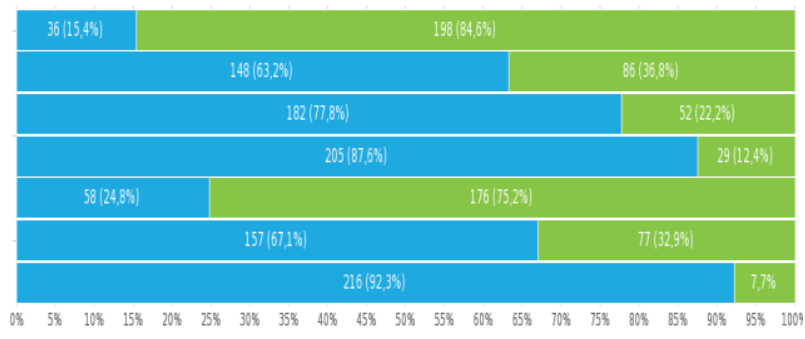

Yes $\square$ No $\square$

Figure 5. Statements and opinions of officials in \%

\section{Conclusions}

The aim of the paper was to present the position of civil servants with a focus on the Czech Republic as an example of good practice. It is clear that in contemporary society the term clerk appears rather in a negative connection, in relation to the organizational structure and bureaucratic apparatus. As the aforesaid, the clerks themselves tend to have a negative view of themselves and the exercise of their profession in their position in society. Although public administration is a managementdriven organization, governed mainly by law, it cannot forget that the human factor is indispensable for the performance and functioning of public administration. Essentially, we could characterize the findings in several key points that apply to this article:

- Modern public administration has undergone several reform stages over the last twenty years, which has resulted in the strengthening of local government and decision-making in it.

- Thanks to these steps, individual states have strengthened not only the demands placed on civil servants but also the demands on the execution of the authorities towards clients - citizens.

- As a result of these steps, there are often negative views on the authorities themselves and the bureaucracy, often due to the overload of individual positions within the public administration.

- Independent Officials Despite the company's noon performance, they view their position in society and occupation as a mission to be accomplished.

The first part of this article is based on the basic facts concerning public administration and the role of the human factor in it. In the following chapter it analyzes the position and basic structure of public administration in the Czech Republic as in a modern democratic state, which in this respect represents an example of good practice, how the public administration works and the officials themselves. Part of the final part of the article is an analysis of the questionnaire survey of the authors of the article, which was carried out through two questionnaires created for the territorial selfgovernment concerned with a focus on the selected region. These questionnaires were aimed both at officials and clients themselves, who use the services of officials in self-government offices. The article focused on several selected areas of problems that individual officials and clients at the authorities face in everyday contact. Very interesting answers appeared in the questionable question of the aggressive client, which was met by almost eighty-two interviewed officials. Opposite in this respect seems to be the issue of aggressive or arrogant officials, which over eighty percent of clients surveyed met. Another issue that raises discussion on the part of both officials and clients is the issue of performance. Despite the fact that both so-called camps (officials and clients) realize the demandingness of this profession, there is a rather negative view of this performance, even from officials themselves, who perceive this negative perception of their profession in society.

The aforementioned are only marginally selected problems faced by officials and clients in the public administration, but there are still risks that officials are much more at risk in their performance than, for example, employees in the private sector. These risks are identified by the authors of the article in their paper entitled The Difficulty of Official Performing in Public Administration with Focus on the Czech Republic (Kamrádová \& Sciskalová, 2019). They are:

- Social risk: Possible exclusion of employees from society based on strict regulations and exclusion from certain social activities of citizens who are not legally bound by employment.

- Mental risk: There is an increased risk of burnout and psychological extinction due 
to the constant increase in professional demands on employees and the amount of communication with clients.

- Economic risk: The disproportion between the amount of obligations and financial remuneration in the public sector is often the cause of employees leaving the private sector.

The aim of the paper was to describe the position of an official and his performance connected with the view of the difficulty of this profession. The paper uses quantitative methods of research by means of a questionnaire survey in public administration aimed at officials as re-spondents. Other methods used in the paper are analysis, comparison and description. All these methods of research give an overview of the selected view of officials on the performance of their profession in the selected group. The aim of the authors of this article was to stimulate discussion in this area and to make possible recommendations for further research, either practical or theoretical. The literature that is used in this article is mainly focused on legislative documents based on the Czech legal order, but theoretically, it also used professional literature in connection with the focus of the article mostly on the Czech environment.

\section{Contribution}

Authors are welcome to declare any involvement in writing a manuscript (e.g. conception and design of the work, acquisition of data, or analysis and interpretation of data, drafting the article or revising it critically for important intellectual content, etc.).

\section{Disclosure statement}

Authors are required to include a statement at the end of their article to declare whether or not they have any competing financial, professional, or personal interests from other parties.

\section{References}

Bagarova Grzyva, M. (2002). Vzdéláváni úředniků je povinné.

https://moderniobec.cz/vzdelavani-uredniku-je-povinne/

Czech Parliament. (1993). Act no. 1993/1/CZ Coll., constitution of the Czech republic. https://www.zakonyprolidi.cz/cs/1993-1

Czech Parliament. (2002). Act no. 2002/312/CZ Coll., on officials of territorial self-governing units and amending certain other acts as subsequently amended.

https://www.zakonyprolidi.cz/cs/2002-312
Czech Parliament. (2002). Act no. 2002/314/CZ Coll., on establishment of municipalities with a delegated municipal authority and determination of municipalities with extended powers. https://www.zakonyprolidi.cz/cs/2002-314

Czech Parliament. (2003). Act no. 2003/361/CZ Coll., On the service relationship of members of secu-rity forces. https://www.zakonyprolidi.cz/cs/2002-361

Czech Parliament. (2014). Act no. 2014/234/CZ Coll., on state service as subsequently amended. https://www.zakonyprolidi.cz/cs/2014-234

Drucker, P. F. (2010). The new realities. Transaction Publishers.

Frederickson, H. G., Smith, K. B., Larimer, Ch. W., \& Licari, M. J. (2012). The Public Administration Theory Primer. Westwiew Press.

Hendl, J. (2005). Kvalitativní výzkum. Portál.

Institute for Public Administration Prague. (2019). About Institute. https:/www.institutpraha.cz/en/about-institute/

Kamrádová, L., \& Sciskalová, M. (2019). The difficulty of an official performing in public administration with a focus on the Czech Republic. In International Scientific Conference Contemporary Inssues in Business, Management and Economics Engineering, 9-10 May 2019. Vilnius, Lithuania. https://doi.org/10.3846/cibmee.2019.047

Miller, D. (2000). Blackwellova encyklopedie politického myšlení. Barrister \& Principal.

Ministry of the Interior Czech Republic. (2018). Strategický rámec rozvoje.

https://www.mvcr.cz/clanek/strategicky-ramecrozvoje.aspx

Pavlík, M., Hendrych, D., \& Kavěna, M. (2014). Správní věda. Teorie veřejné správy. Wolters Kluwer.

Pracomat. (2019). Platové tabulky a třidy státnich zaměstnanců 2020.

https://www.pracomat.cz/poradna/propracujici/228-platy-statnich-zamestnancu.html

Šabatová, A., Hampl, S., Maříková, H., Urbaníková, M., \& Kvasnicová, J. (2017). Harmonising one's professional, personal and family life at ministries in the Czech Republic.

https://www.ochrance.cz/fileadmin/user_upload/E SO/101-2017-DIS-JKV-vyzkumna_zprava.pdf

Ticháčková, J. (2019). OECD doporučí, jak zefektivnit poskytování veřejných služeb v České republice, Veřejná správa, $X X X(19), 14-15$.

Wiesnerová, E. (2015). Neustálé reformy veřejné správy jsou nesmysl. https://www.online.muni.cz/veda-avyzkum/5794-neustale-reformy-verejne-spravyjsou-nesmysl

Zimek, J. (2010). Ústavnost a český ústavní vývoj. Masarykova univerzita. 